Marquette University

e-Publications@Marquette

$10-1-2004$

\title{
Effect of Therapist Color-Blindness on Empathy and Attributions in Cross-Cultural Counseling
}

\author{
Alan W. Burkard \\ Marquette University, alan.burkard@marquette.edu \\ Sarah Knox \\ Marquette University, sarah.knox@marquette.edu
}

Accepted version. Journal of Counseling Psychology, Vol. 51, No. 4 (October 2004): 387-397. DOI. This article may not exactly replicate the final version published in the APA journal. It is not the copy of record. 


\title{
Effect of Therapist Color-Blindness on Empathy and Attributions in Cross-Cultural Counseling
}

\author{
Alan W. Burkard \\ Department of Counseling and Educational Psychology, School of \\ Education \\ Marquette University \\ Milwaukee, WI \\ Sarah Knox \\ Department of Counseling and Educational Psychology, School of \\ Education \\ Marquette University \\ Milwaukee, WI
}

\begin{abstract}
Empathy and attributions of client responsibility for the cause of and solution to a problem were examined for 247 psychologists who were identified as having low, moderate, and high color-blind racial attitudes. Participants responded to 1 of 4 vignettes that controlled for client race (i.e., African American, European American) and client attributions regarding the cause (i.e., depression, discrimination) of a problem. Analyses revealed that the therapists' level of color-blindness was directly related to their capacity for empathy and also to their attributions of responsibility for the solution to the problem with an African American client but not with a European American client. No relationship was found between therapist color-blindness and attributions of responsibility for cause of the problem. Implications of these results for counseling practice, training, and research are discussed.


The original conceptualization of cross-cultural counseling competencies identified 11 specific competencies related to counselor awareness of her or his attitudes and beliefs, knowledge, and skills (D. W. Sue et al., 1982). Counselor awareness of racism and oppression in oneself and the effect of racism on others, for example, are considered fundamental to multicultural counseling (e.g., Neville, Worthington, \& Spanierman, 2001; D. W. Sue et al., 1982; D. W. Sue \& Sue, 2003). Without such awareness, therapists' own biases may perpetuate oppression against racial-ethnic minority clients during the psychotherapy process (Helms, 1984).

Despite the theorized importance of therapists' awareness of their own racial attitudes and beliefs, examination of the relationship between therapist racial attitudes and certain kinds of decision making in psychotherapy has received limited empirical attention. In what little research that has been done in this area, researchers have found that therapists who rated themselves as high in negative racial attitudes also rated themselves lower in multicultural counseling competency (Constantine, 2002; Constantine, Juby, \& Liang, 2001). Although these studies establish a correlational relationship between therapists' selfreported racial attitudes and cross-cultural counseling competencies, we do not know whether these findings may be extended to therapists' reactions and decisions in counseling. Thus, an examination of the effect of therapists' racial attitudes on their reactions and decisions in counseling may be an important focus for research and could have implications for multicultural counseling competence as well as therapist training and practice.

In addition to affecting multicultural counseling competency, therapist racism toward culturally different clients may also explain some of the discrepancies found in research on clinical judgment about, and service delivery to, White clients and ethnic-racial minority clients. For example, research suggests that in comparison to their White counterparts, racial-ethnic minority clients' level of psychopathology is overestimated (Gynther, 1972, 1979), their prognosis is often underestimated (Butcher, Braswell, \& Raney, 1983), they are engaged in shorter periods of treatment (Yamamoto, James, Bloombaum, \& Hattem, 1967), they are referred to more restricted forms of treatment (Gynther, 1979; Krebs, 1971), and they have higher termination rates from treatment (S. Sue, Fujino, Hu, Takeuchi, 
\& Zane, 1991; Terrell \& Terrell, 1984). Although this research is dated, it is, in fact, the most recent such research available. Nevertheless, these investigations do highlight the evidence that suggests the existence of bias in the treatment of racial-ethnic minority clients.

Not all investigations, however, support this implied hypothesis of bias. Garb (1997), for instance, conducted a review of the literature on bias in clinical judgment, concluding that "for many important tasks, bias related to the collection and/or integration of information does not seem to be present or, if present, seems to be in a direction that favors groups that have historically been discriminated against" (p. 113). Some researchers have suggested that methodological confounds (e.g., use of analogue studies, social desirability effects, not controlling for level of psychopathology) in the research on bias in therapy may account for these discrepant findings in the literature (Abramowitz \& Murray, 1983; Garb, 1997).

Although methodological confounds may well be a concern in research on therapist bias in therapy, it is also important to note that none of the investigations cited in these reviews included a measure of therapist racial bias in the research design. For example, prior investigations on therapist bias would typically assign a study participant to an African American or European American client condition, assess the participant on a typical task in therapy (e.g., diagnosis, goal setting), and then compare the results found in the African American client condition with that of the European American condition (e.g., Bamgbose, Edwards, \& Johnson, 1980; Pavkov, Lewis, \& Lyons, 1989). If differences were found, bias was often an explanation, and in cases in which differences were not found, researchers would often conclude that bias did not occur. Conceptually, it becomes problematic to draw a conclusion about therapist bias, when in fact therapist bias was not measured and included as a variable in the research design. To date, research has not directly examined the effect of therapists' racial biases on psychotherapy processes (Atkinson \& Lowe, 1995; Ponterotto, Fuertes, \& Chen, 2000). It is this omission that the present study seeks to address.

Before we examine the possible relationship of racism to therapist actions in counseling, we must clarify the definition of racism 
used in this study. Early theories conceptualized racism as overt attitudes and behaviors that were used to limit the rights and freedoms of African Americans (McConahay, 1986). Kovel (1970) wrote that a racist individual "acts out bigoted beliefs-he represents the open flame of racial hatred" (p. 54). In contrast, contemporary theories of racism reflect the multidimensional nature of racial prejudice and acknowledge not only overt bigotry, as identified above, but also more subtle and less overt forms of prejudice (Burkard, Medler, \& Boticki, 2001). These later conceptualizations of racism assert that individuals may simultaneously have contradictory feelings of egalitarianism and negativity toward racially-ethnically diverse groups, a contradiction that may result in expressed attitudes of equality that are contrasted by behaviors that demonstrate racial bias (Gaertner \& Dovidio, 1986; McConahay, 1986). One way of reconciling this contradiction (i.e., between feelings of egalitarianism and concurrent negative attitudes toward racially diverse people) is to deny that racial issues matter in people's lives, or to be "color-blind" (American Psychological Association [APA], 1997; Schofield, 1986; Williams, 1997).

Thus, although racial prejudice is admittedly a multidimensional construct, in this study we were interested in examining a more subtle form of racism, that of color-blind racial attitudes, for two reasons. First, measures of overt racism have been highly susceptible to social desirability attitudes (e.g., Gaertner \& Dovidio, 1986; McConahay, 1986). However, measures of more subtle forms of racism (e.g., colorblind racial attitudes) appear to be less susceptible (Burkard et al., 2001; Ponterotto et al., 1995). Thus, we sought to include a measure that would be less susceptible to the effects of social desirability. Second, measures of subtle racism have focused predominately on the attitudes of European Americans, whereas color-blindness is believed to be applicable to many racially and ethnically diverse groups (Neville, Lilly, Duran, Lee, \& Browne, 2000). Thus, we sought to include a measure of subtle racism (i.e., Color-Blind Racial Attitudes Scale; COBRAS; Neville et al., 2000) that would provide for the opportunity to replicate this study with psychologists from diverse racial and ethnic backgrounds.

Color-blind racial attitudes are defined as "the belief that race should not and does not matter" (Neville et al., 2000, p. 60). This 
definition is founded on the notion that all racial-ethnic groups are and should be socially and economically equal. Individuals who hold colorblind racial attitudes tend to deny the individual, institutional, and cultural manifestations of racism and believe that race has little meaning in people's lives.

In contrast to these beliefs, however, various population statistics suggest that racially diverse groups are neither socially nor economically equal in the United States. For example, the United States has continued to see a rise in the formation of hate groups (Serrano, 1998), unemployment rates among African Americans consistently remain double those of European Americans (U.S. Department of Commerce, 1998), and annual incomes of people of color remain disproportionately lower than those of European Americans (U.S. Department of Commerce, 1998). Those who hold color-blind racial attitudes, however, would likely continue to believe that race has no part in these disparities and instead may explain these differences as a lack of effort by racial-ethnic minorities. Without a conscious awareness of racism and privilege, counselors who hold such beliefs may unwittingly perpetuate racism in the psychotherapy process. As an illustrative example, counselors may minimize or ignore reports of discrimination and prejudice in school, at work, or in the community by clients of color. Furthermore, if they remain unaware of the effects of racism, they may be unlikely to address issues of racism in psychotherapy and may not intervene on a client's behalf with systems that are racist and oppressive. In essence, counselors who endorse high levels of color-blind racial attitudes may be more inclined to be unresponsive to racial issues and to the effects of racism on clients during counseling sessions.

Although the effect of color-blind racial attitudes on the therapeutic process has not been directly studied, research evidence from client reports suggests that counselors who were culturally responsive (perhaps a reflection of the degree to which a therapist is color-blind) were rated as more credible and culturally competent (Atkinson, Casas, \& Abreu, 1992; Gim, Atkinson, \& Kim, 1991; Pomales, Claiborn, \& LaFromboise, 1986), reported higher client satisfaction and lower client attrition rates from counseling (Wade \& Bernstein, 1991), and had clients who self-disclosed more intimately (Thompson, Worthington, \& Atkinson, 1994) than did counselors who 
were culturally unresponsive. Furthermore, Thompson and Jenal (1994) found that African American women became more frustrated and exasperated with counselors, regardless of their racial background (i.e., African American, European American), when the counselors actively avoided racial content in counseling. These prior investigations focused on client perceptions of the counselor after cultural sensitivity training as well as clients' perceptions of counselor cultural responsiveness and unresponsiveness in cross-cultural counseling. Although there may be other explanations for counselors' cultural unresponsiveness (e.g., counselors' discomfort discussing racial issues, counselors' level of multicultural training), perhaps unresponsiveness to cultural issues and decreased cultural sensitivity are manifestations of counselors' color-blind racial attitudes. This potential conceptual link between therapist color-blindness and their reactions and actions with culturally diverse clients in therapy is worthy of further examination. For this study, then, we proposed that therapists' color-blind racial attitudes would directly affect their reactions (i.e., empathy, attributions) in therapy.

In this investigation, we were interested in two types of therapist reactions in multicultural counseling. First, we examined therapists' feelings of empathy toward racially diverse clients. Empathy is a foundational disposition in counseling (Bohort, Elliot, Greenberg, \& Watson, 2002) and has been found to be one of the most important factors in discriminating effectiveness in therapy (Bohort et al., 2002; Lafferty, Beutler, \& Crago, 1989). Empathy is also considered essential to cross-cultural counseling (Ho, 1992; Ridley \& Lingle, 1996). It is believed that therapists' expression of empathy in a culturally responsive manner may be a determining factor in culturally diverse clients' perception of therapist cultural sensitivity during assessment and treatment (Fischer, Jome, \& Atkinson, 1998). Although research is limited, one investigation found that counselors high in affective empathy were more aware of cultural factors in conceptualizing client issues than were counselors low in affective empathy, and counselors high in affective and cognitive empathy demonstrated increased capacity to conceptualize cultural issues in client treatment (Constantine, 2001). These findings suggest that empathy is potentially an important component in the counseling of culturally diverse clients. 
Although Constantine's (2001) research has indicated that empathy may be an important factor in cross-cultural counseling, we do not know what specific therapist characteristics may influence their capacity to be empathic in multicultural counseling settings. The present study thus sought to examine the effect of one such characteristic (i.e., color-blind racial attitudes) on therapists' capacity for empathy toward an African American or a European American client when the client attributed his or her problem to depression (i.e., internal cause) or racial discrimination (i.e., external cause).

A second type of therapist reaction we examined was therapists' attributions of clients' responsibility for causing and solving their problems. Attributions of cause of the problem have been defined as the responsibility and control one has for the origin of a problem and specifically refer to whether the individual or the environment is responsible. Attributions of solution to the problem involve an assessment of whether the individual or the environment is responsible for and in control of any future events related to the resolution of the problem. Therapist attributions regarding cause of and solution to client difficulties in counseling are important because they may affect the process and outcome of therapy (Brickman et al., 1982). For example, clients have been found to terminate counseling prematurely when their explanation of the problem cause did not match that of the therapist (Tracey, 1988). Although research has not examined the reason for the lack of match between client and therapist attributions, theorists in multicultural counseling believe the difference between therapist and client attributions of cause of and solution to client problems may be a result of differences in client and counselor worldviews (D. W. Sue \& Sue, 2003). Some clients' cultural value systems (e.g., Asian American, Native American), for instance, emphasize fatalism or external causes for client difficulties (LaFromboise, 1988; Leong, 1985; Root, 1998). In contrast, research indicates that therapists often are more inclined to emphasize an internal locus of control for client problems (Donnan \& Pipes, 1985; Tracey, 1988), unless there is a clear external precipitant for the client's concern (Hayes \& Wall, 1998; Worthington \& Atkinson, 1996). These contrasting perspectives may lead to therapists encouraging clients to accept responsibility for their actions, whereas clients who have a more fatalistic perspective of the world may seek to understand the external causes of their difficulties. Furthermore, therapist 
responsibility attributions have been found to be relatively unaffected by client responsibility attributions (Hayes \& Wall, 1998). The combination of these research findings seems to suggest that therapists typically attribute internal causes for client difficulties and may be unwilling to alter their perspectives even when presented with an alternative explanation by their clients. Such conflicts in client and therapist worldview and attribution styles may result in poor therapy outcomes for the client (e.g., premature termination, lack of compliance with therapy goals) and may provide culturally diverse clients with reasons to distrust counseling services (Ridley, 1995; D. W. Sue \& Sue, 2003). Consequently, identifying specific therapist characteristics (i.e., color-blindness) that moderate their attributions in multicultural counseling appears to be important to study.

Of concern to the multicultural counseling process is the influence that color-blind racial attitudes may have on therapists' attributions, because these attitudes may interfere with therapists' ability to accurately discern the difference between internal (i.e., depression) and external (i.e., racism) causes for a client's problem. Or perhaps, color-blindness may interfere with therapists' acknowledgment of the validity of the client's attributions. As an illustration, traditional theories of career development typically emphasize individualistic and self-actualizing perspectives regarding a client's career choice and behaviors rather than considering the effect of racial discrimination (Leung, 1995; Smith, 1983). Therapists who fail to recognize the effect of racial discrimination on career behavior may be especially vulnerable to therapeutic errors, particularly when working with clients of color. For instance, a therapist may attribute an African American's unsuccessful attempts to obtain employment to a lack of effort or lack of skills rather than to biased hiring practices. Consequently, if therapists do not make an accurate assessment of the problem cause, particularly when the client's presenting concern involves racism, the therapist's misattribution may result in a poor therapeutic outcome for the client (e.g., increased distress, premature termination from counseling). In the present investigation, we examined the effect of therapist color-blind racial attitudes on their attributions of client responsibility for the cause of and solution to a problem when the client attributed the problem to depression (i.e., internal) or racial discrimination (i.e., external). 
NOT THE PUBLISHED VERSION; this is the author's final, peer-reviewed manuscript. The published version may be accessed by following the link in the citation at the bottom of the page.

\section{Research Questions}

Therapists' color-blindness, feelings of empathy, and attributions of client responsibility for the cause of and solution to a problem may each have important implications for cross-cultural counseling, and the relationship among these factors is worthy of investigation. Theory on color-blind racial attitudes presumes that individuals who are high in these beliefs will deny the role and influence of race in people's lives and that these beliefs will result in actions that may be more consistent with racial prejudice rather than with social justice (Neville et al., 2001). Consistent with this perspective, we hypothesized that those therapists who were higher in color-blind racial attitudes would show less empathy for an African American client than for a European American client. Furthermore, we expected that the client's attributions of the source (i.e., depression, discrimination) of the problem would qualify the ratings of empathy with the African American client but not with the European American client. Second, we predicted that therapists' color-blindness would be related to their attributes of responsibility for cause of the problem for the African American client and would not effect their attributions for the European American client. Again, we expected that these effects would be moderated by the client's attributions of the source (i.e., depression, discrimination) of the problem. Finally, we predicted therapists' color-blind racial attitudes would also be related to their attributions of responsibility for the solution of the problem for the African American client and not the European American client. We expected that these effects would also be moderated by clients' attributions of the source (i.e., depression, discrimination) of the problem. Because research has indicated that social desirability is a potentially confounding variable in multicultural studies (Constantine \& Ladany, 2000), we also examined social desirability as a covariate for this study. 
NOT THE PUBLISHED VERSION; this is the author's final, peer-reviewed manuscript. The published version may be accessed by following the link in the citation at the bottom of the page.

\section{Method}

\section{Participants}

Participants consisted of 247 practicing psychologists (133 men, 114 women) who were members of the APA. Participants were between the ages of 33 and 76 years old $(M=51.90, S D=7.68)$ and had practiced as psychologists between 4 and 43 years $(M=19.16$, $S D=7.47)$. The sample consisted of 4 African Americans, 2 Asian Americans, 234 European Americans, 4 Latina/Latinos, 1 Native American, and 2 participants who identified as biracial. The largest number of respondents identified as clinical psychologists $(n=176)$, with counseling psychologists as the next largest group $(n=36)$; the remaining 35 participants identified "other" as their specialization (i.e., counseling, neuropsychology, school psychology). To determine the representativeness of our sample, chi-square analyses were conducted for age, gender, race, degree status, and specialization for the study respondents for the entire sample of 800 practitioners obtained from the APA Practice Directorate and for the general characteristics of the members of the APA Practice Directorate. None of these chi-square analyses was statistically significant, thus suggesting that our respondents were demographically similar to the members of the APA Practice Directorate and also to the sample of 800 psychologists obtained for this study from that directorate with regard to the variables of age, gender, race, degree status, and specialization.

\section{Instruments}

Empathy. The Interpersonal Reactivity Index (IRI; Davis, 1983) is a 28-item self-report measure that consists of four 7-item subscales: Fantasy, Empathic Concern, Perspective-Taking, and Personal Distress. Respondents rate each item on a 5-point scale ranging from 0 (does not describe me well) to 4 (describes me very well), and subscale and total scale scores are obtained by summing item responses. Subscale scores range from 0 to 28, and higher scores suggest greater levels of respondent empathy. A review of subscale items indicated that the Empathic Concern and Perspective-Taking subscales corresponded more directly with conceptual definitions of empathy (i.e., Bohort et al., 2002; Ridley \& Lingle, 1996), whereas the 
Fantasy and Personal Distress subscales did not correspond with recognized conceptualizations of empathy (Constantine, 2001; Hayes \& Erkis, 2000). Thus, paralleling past research (i.e., Constantine, 2000), the Empathic Concern and Perspective-Taking subscales were the only subscales used for this investigation. The Empathic Concern subscale assesses one's ability to experience feelings of compassion, warmth, and concern for others. A sample item is "When I see someone being taken advantage of, I feel kind of protective towards them." The Perspective-Taking subscale measures a person's tendency to consider others' perspectives and points of view (i.e., "I try to look at everybody's side of a disagreement before I make a decision").

The internal reliability measures of the IRI (Davis, 1983) subscales have been reported to range from.71 to.77 (Davis, 1980). Constantine (2001) recently reported a coefficient alpha of.72 for the Empathic Concern subscale and.63 for the Perspective-Taking subscale. The coefficient alpha for the present study was.69 for the Empathic Concern subscale and.72 for the Perspective-Taking subscale. Evidence of construct validity for the IRI subscales is presented in a few investigations (Bernstein \& Davis, 1982; Davis, 1980). Davis, Hull, Young, and Warren (1987) provided evidence that the Empathic Concern and Perspective-Taking subscales measure the emotional and cognitive aspects of empathy.

Attribution of responsibility measures. Clinician attributions of client responsibility for the cause of and solution to a problem were assessed by Cause and Solution Scales developed by Karuza, Zevon, Gleason, Karuza, and Nash (1990). Each scale comprises three items. The Cause Scale items assess the participant's belief that a client is personally responsible for the cause of a problem, could have avoided the problem, and could have controlled the cause of the problem. The Solution Scale items reflect the respondent's belief that the client is personally responsible for creating a solution to the problem, overcoming the problem alone, and the extent to which the person has control over the solution to the problem. Items are rated from 1 (not at all) to 7 (very much), and scale scores are computed by summing item responses. Scale scores range from 3 to 21 for each scale. Higher scores reflect higher clinician attributions of client responsibility for causing and solving the problem. 
Internal consistency measures have ranged from.61 to.87 for the Cause Scale and from.63 to.74 for the Solution Scale (Bailey \& Hayes, 1998; Karuza et al., 1990). For the present study, the coefficient alphas were.79 for the Cause Scale and.76 for the Solution Scale. A 2-week test-retest reliability has been estimated at. 86 for the Cause Scale and at.70 for the Solution Scale (Bailey \& Hayes, 1998). McCracken, Hayes, and Dell (1997) demonstrated concurrent validity evidence by showing that the Cause and Solution scales correlated in positive predicted directions with the Derived Cause and Derived Solution scales of the Helping Coping Orientation Measure (Michlitsch \& Frankel, 1989). Construct validity evidence has been provided by Hayes and Wall (1998), who demonstrated that clinicians rated clients diagnosed with posttraumatic stress disorder as significantly less responsible for the cause of and solution to a problem in comparison to clients diagnosed with bulimia.

Marlowe-Crowne Social Desirability Scale (MCSDS; Crowne \& Marlowe, 1960). The MCSDS was developed by Crowne and Marlowe (1960) and is intended to measure a respondent's motivation to behave in a socially desirable manner. The MCSDS contains 33 items, and participants respond by answering true or false to each item. Sample items include "Before voting I thoroughly investigate the qualifications of all the candidates" and "I never hesitate to go out of my way to help someone in trouble." Scale scores range from 0 to 33, and higher scores reflect a high need for approval in the respondent. Reported coefficient alphas range from.73 to.88 (Paulhus, 1991). The validity evidence on the MCSDS suggests the scale taps one aspect of socially desirable behavior: a respondent's motivation for impression management (Paulhus, 1984, 1991). The coefficient alpha for the MCSDS for this study was.65.

COBRAS (Neville et al., 2000). The COBRAS was developed by Neville et al. (2000) to measure the extent to which an individual may deny racism and the effect of race on people's lives. The COBRAS consists of 20-items, which are rated on a 5-point scale that ranges from 1 (not at all appropriate or clear) to 5 (very appropriate or clear). Three aspects of color-blind racial attitudes are tapped by the COBRAS: (a) Racial Privilege, which refers to the denial of White privilege (7 items); (b) Institutional Discrimination, which suggests 
that individuals remain unaware of discriminatory institutional practices (7 items); and (c) Blatant Racial Issues, which suggests the denial of the pervasiveness of discrimination and racism in our society ( 6 items). Scores are determined by summing item responses, and total scale scores range from 20 to 100 . Higher scores reflect higher levels of color-blindness in respondents. Sample items include "Race is very important in determining who is successful and who is not" and "It is important that people begin to think of themselves as American and not African American, Mexican American, or Italian American."

Neville et al. (2000) reported coefficient alphas of.86-.91, for the total score across three initial development studies for the COBRAS, and a 2-week test-retest reliability coefficient of.68. For the present study, a coefficient alpha of. 88 was obtained for the sample. The COBRAS demonstrates moderate to strong correlations with two measures of racial discrimination (i.e., Modern Racism Scale; McConahay, 1986; Quick Discrimination Index; Ponterotto et al., 1995), providing evidence of concurrent validity evidence. Both an initial exploratory factor analysis and a confirmatory factor analysis provided evidence of construct validity, and a low, insignificant correlation with the MCSDS (Crowne \& Marlowe, 1960; Reynolds, 1982) provides evidence of discriminant validity.

Manipulation of race of client and source of the client problem. Four clinical vignettes were developed for this study, designed to experimentally manipulate race of the client (i.e., African American, European American) and client attributions for the cause (i.e., depression, discrimination) of their problem. Each vignette was approximately 250 words in length and identified the client as an 18year-old male, first-year college student living for the first time in a residence hall. The client indicated that he was seeking counseling services because of the isolation he felt from other students in his residence hall. He described experiencing symptoms of depression (i.e., social isolation, active avoidance of social connection, depressed feelings, lack of interest in pleasurable activities) and overall feelings of homesickness. In the vignettes, the client attributed his difficulties either to feelings of depression and social isolation (i.e., the depression condition) or to active exclusion on the basis of race by residents who were racially different from him (i.e., the discrimination condition). The 
client indicated that he was seeking help because he was considering leaving or transferring from this college.

\section{Procedure}

Eight hundred APA members who identified as practicing psychologists were selected at random by the APA's Research Office as potential participants. These members were sent a prenotification letter that described the purpose of the study, outlined the procedures, and requested their voluntary participation. Approximately 1 week later, research packets were sent to participants. Each packet contained one of the four randomly assigned vignettes (an African American or European American client who identified the source of his difficulty as depression or racial discrimination), the Cause and Solution Scales, the IRI (Davis, 1983), the MCSDS (Crowne \& Marlowe, 1960), the COBRAS (Neville et al., 2000), an informed consent letter, and a prepaid return envelope. All measures were counterbalanced to control for ordering effects. Upon the researchers' receipt of participants' completed materials, informed consent forms were separated to protect the confidentiality of participants. Two follow-up mailings were sent to encourage additional participation. Fourteen packets were returned as undeliverable because of wrong addresses, and 22 were returned with the respondent indicating that he or she never was or no longer was a practicing psychologist. Of the remaining 764 potential survey participants, 247 participants returned completed survey packets. This represents a return rate of $32 \%$.

\section{Results}

\section{Preliminary Analyses}

Prior to the main analyses, we examined the independent and dependent variables for violations of the assumptions of normality (Stevens, 2002). Examination of kurtosis and skewness estimates for all variables indicated that variable ranges fell between -.23 and 1.60 for kurtosis and -.62 and.47 for skewness, which are considered acceptable ranges and an indication of a normal distribution for all variables. We also examined the covariance matrices for the dependent variables for equality using Box's test of equality of 
covariance matrices (SPSS, 1999), and the results were nonsignificant, $F(33,102475.1)=1.15, p<.26$. Additionally, Levene's test of homogeneity of variance was also nonsignificant for all dependent variables: empathy, $F(11,235)=1.71, p<.07$; cause of the problem, $F(11,235)=0.82, p<.62$; and solution to the problem, $F(11,235)=$ $0.63, p<.80$. This combination of findings suggests that the assumptions for using analysis of covariance (ANCOVA) and multivariate analysis of covariance (MANCOVA) in the data analysis have not been violated.

The relationships between independent and dependent variables were obtained through a series of Pearson correlation coefficients, which are presented in Table 1. In general, correlations between the MCSDS (Crowne \& Marlowe, 1960) and the dependent variables were statistically significant, an indication that participants with a higher need to respond in a socially desirable manner gave higher ratings of empathy and also more highly attributed responsibility to clients for the cause of and solution to a problem. Because of the statistically significant relationship between social desirability ratings and the dependent variables of empathy and attributions of client responsibility for cause of and solution to the problem, we used MCSDS scores as a covariate in the main data analyses. Additionally, COBRAS (Neville et al., 2000) and MCSDS scores were not correlated, suggesting no immediate relationship between color-blindness and social desirability. Also of interest is the statistically significant positive correlation found between COBRAS scores and attributions of client responsibility for the cause of the problem, indicating that higher levels of color-blindness were associated with greater attributions of responsibility to clients for the cause of the problem. We found a statistically significant inverse relationship between COBRAS and empathy scores, suggesting that higher levels of color-blindness were correlated with lower empathy ratings.

To determine whether participant gender should be entered into the analysis as an independent variable, we computed a MANOVA for the three dependent measures (i.e., empathy, therapist attributions of cause, and attributions of solution). The multivariate $F$ test was not statistically significant; thus, it was determined that gender of the respondents would not be included in the final analysis of data. Additionally, we computed Pearson correlation coefficients between 
participant age and years in clinical practice, and each dependent variable, to determine whether either of these characteristics should be included as independent variables. Because none of these correlations reached statistical significance, it was again concluded that participant age and number of years in clinical practice would not be included in the main data analysis.

Because we wanted to examine how different levels (i.e., low, moderate, high) of therapist color-blind racial attitudes may affect the dependent variables of empathy and therapist attributions, we divided the participants into three equivalent groups on the basis of their COBRAS (Neville et al., 2000) scores. We created the three COBRAS groups using the 33.33 and 66.66 percentiles, with participants then identified as low $(M=39.05, S D=5.55)$, moderate $(M=51.79, S D=$ 3.52), and high ( $M=68.70, S D=9.22)$ with respect to color-blind racial attitudes. We also wanted to ensure that there were no statistically significant differences for color-blindness ratings within each level of the three COBRAS groups across the four vignettes. We computed one-way ANOVAs for each level (i.e., low, moderate, high), using the total COBRAS score as the dependent variable and the four client vignettes as the independent variables. None of the $F$ values reached statistical significance, which suggests that COBRAS scores did not vary across client vignettes within the three levels (i.e., low, moderate, high) of COBRAS scores. Means and standard deviations for each of the dependent variables are provided in Table 2.

To test the research hypotheses, we used both univariate and multivariate data analysis procedures. We set the familywise error rate at.01 per hypothesis. Because empathy scores were not significantly correlated with either the attributions of responsibility for cause of the problem $(r=-.01)$ or attributions of responsibility for solution to the problem $(r=.09)$, we conducted a separate ANCOVA to test the related hypothesis, as recommended by Stevens (2002).

\section{Therapist Empathy Analyses}

In the first hypothesis, we predicted that there would be significant differences in empathy among therapists from the three color-blindness levels for the African American client but not the European American client. We computed a 2 (client race) $\times 2$ (client 
attribution of source of the problem) $\times 3$ (color-blindness) ANCOVA, with social desirability as the covariate, for therapist empathy ratings. When entered as a covariate, social desirability significantly contributed to the model, $F(1,234)=3.88, p=.05, \eta^{2}=.02$, suggesting that therapists were motivated by their need for approval. The main effect for therapist level of color-blindness was statistically significant, $F(2,234)=3.52, p=.03, \eta^{2}=.03$, which suggests that therapist level of color-blindness significantly influenced ratings of empathy. Pairwise comparisons indicated that therapists high in colorblind racial attitudes rated themselves as less empathic ( $M=40.20$, $S D=6.05$ ), or less able to feel warmth, caring, and compassion toward others regardless of their racial background, in comparison to therapists low in color-blindness $(M=42.53, S D=6.09)$. Therapists with moderate color-blind attitudes $(M=41.12, S D=4.75)$ were not found to be statistically significantly different from either the low- or high-color-blindness groups. The main effects for race of client, $F(1$, 234) $=0.29, p=.06, \eta^{2}=.00$, and client attribution regarding source of the problem, $F(1,234)=0.01, p=.92, \eta^{2}=.00$, were not significant. These findings indicate that race of the client and client attributions regarding the source of the problem were not factors in empathy ratings. Furthermore, the interaction effects of race of client and client attributions of the source of the problem, $F(2,234)=3.52$, $p=.03, \eta^{2}=.03$; race of client and therapist color-blindness, $F(2,234)$ $=0.75, p=.39, \eta^{2}=.00$; therapist color-blindness and client attributions of the source of the problem, $F(2,234)=0.78, p=.46, \eta^{2}$ $=.00$; and the three-way interaction of client attributions of the source of the problem, client race, and therapist color-blindness, $F(2,234)=$ $0.27, p=.76, \eta^{2}=.00$, were not statistically significant.

\section{Therapist Attribution Analyses}

For the second and third hypotheses, we predicted that therapists' color-blind racial attitudes would predict their attributions of responsibility for the cause of and solution to a problem for an African American client and not for a European American client. Furthermore, we expected that these effects would be moderated by clients' attributions regarding the source of their problem (i.e., depression, discrimination). We analyzed therapist attribution ratings of client responsibility for the cause of and solution to the problem using a 2 
(client race) $\times 2$ (client attribution regarding the source of the problem) $\times 3$ (color-blindness) MANCOVA, with social desirability as the covariate. Social desirability did significantly contribute as a covariate to the multivariate model, $F(2,234)=5.69, p=.004, \eta^{2}$ $=.05$, suggesting that therapists' need to be seen in a favorable manner influenced their attributions for cause of and solution to a problem. Using Wilks's criteria, we found statistically significant multivariate effects for client race, $F(2,336)=8.87, p=.000, \eta^{2}=.07$, and client attribution regarding the source of the problem, $F(2,233)=$ $6.34, p=.002, \eta^{2}=.05$, and we found an interaction effect for client race and therapist color-blindness, $F(4,466)=3.29, p=.01, \eta^{2}=.03$. Multivariate effects were not found to be statistically significant for the main effect of therapist color-blindness, $F(4,466)=1.89, p=.11, \eta^{2}$ $=.01$. The interaction effects of Client Race $\times$ Client Attribution regarding the source of the problem, $F(2,233)=1.43, p=.24, \eta^{2}$ $=.01$; Client Attribution Regarding the Source of the Problem $\times$ Therapist Color-Blindness, $F(4,466)=1.29, p=.27, \eta^{2}=.01$; or the three-way interaction of Client Race $\times$ Client Attribution Regarding the Source of the Problem $\times$ Therapist Color-Blindness, $F(4,466)=0.71$, $p=.58, \eta^{2}=.00$, were also found not to be statistically significant.

Because interaction effects qualify the main effects (Stevens, 2002), here, we only present the follow-up univariate $F$ tests for the interaction effects of Client Race $\times$ Therapist Color-Blindness. The univariate $F$ tests revealed that therapists' attributions regarding the cause of the problem were not significant, $F(2,234)=1.58, p=.21, \eta^{2}$ $=.01$, but therapists' attributions for solution to the problem were found to be significant, $F(2,234)=5.86, p=.003, \eta^{2}=.05$. These findings indicate that level of therapist color-blindness and race of the client predicted therapists' attributions of client responsibility for the solution to the problem but not for cause of the problem.

To test the interaction of client race and therapist colorblindness, we conducted an ANOVA, with therapist attributions of responsibility for the solution to the problem as the dependent variable, holding client race as a constant. When we compared the therapists across the three levels of color-blindness for the African American client, we found statistically significant differences for attributions of client responsibility for the solution to a problem, $F(2$, $124)=4.64, p=.01$. Inspection of the pairwise comparisons indicated 
that therapists high in color-blind racial attitudes $(M=16.76, S D=$ 2.55) held African American clients more responsible for the solution of problems than did therapists who were low in color-blind racial attitudes $(M=15.12, S D=2.68)$. Therapists who were categorized in the moderate-color-blindness group were not found to differ significantly from therapists in the low- or high-color-blindness groups in terms of their attribution ratings of client responsibility for solution to the problem.

In the second analysis, we compared therapists across the three levels of color-blindness for the European American client and found the results were not statistically significant for attributions of client responsibility for the solution to a problem, $F(2,117)=1.34, p=.26$. These findings indicate that therapists' level of color-blindness was not a factor in the attributions of responsibility for the solution to a problem with the European American client.

\section{Discussion}

The data show that therapists' self-reported ratings of empathy and their attributions of client responsibility for the cause of and solution to a problem were statistically significant and positively related to higher levels of social desirability, indicating that psychologists in this study were motivated to respond in a socially desirable manner. It may not be surprising that these participants were inclined to respond in a way that would portray them in a more favorable manner. First, participants were informed that this investigation was examining how color-blind racial attitudes may influence their reactions (i.e., empathy, attributions) in therapy. Additionally, the face validity of the COBRAS (Neville et al., 2000) measure may have also influenced participant reactions. Given that the sample of psychologists for this study was predominately European American, a socially desirable response, such as responding to the instruments on the basis of how one would like to be perceived by others rather than what one would actually do, may reflect racerelated guilt (Baldwin, 1965/1998; Helms, 1990). In the only directly related research, however, Constantine (2000) found that social desirability was not correlated with therapist empathy (as measured by the IRI; Davis, 1983). To clarify this inconsistency, further research 
is needed that examines the relationship between social desirability and multicultural counseling processes such as establishing empathy and making attributions with culturally diverse clients. Perhaps one implication of the present and past findings is that social desirability may be an important concern generally in multicultural counseling research. Consequently, it may be prudent for future multicultural researchers to account for social desirability influences in their research designs.

After controlling for social desirability, three important findings emerged here. First, therapist color-blind racial attitudes were directly related to therapist self-reported ratings of empathy. More specifically, those therapists who scored high on color-blindness reported having significantly less empathy than did those who scored in the low range for color-blind racial attitudes. Essentially, psychologists who were less color-blind, and thus willing to acknowledge that race matters in people's lives, showed more empathy than those who were color-blind to race and racism. Furthermore, an interaction effect with client race did not emerge, indicating that regardless of client race, therapists who were less color-blind were more empathic with clients than were therapists who were high in color-blindness. One possible implication of this finding is that therapists may need to develop their sensitivity to racial issues to increase their overall capacity for empathy in therapy. Thus, rather than viewing multicultural counseling training as supplementary training, such training may be more appropriately viewed as central to the development of sensitive and caring practitioners.

The relationship found here between therapist color-blindness and empathy study may also help explain the positive relationship found between self-reported levels of empathy and increased awareness of cultural issues in conceptualizing client concerns and therapy found in prior research (Constantine, 2001). It may be, for example, that therapists' color-blindness (i.e., minimal awareness of racial issues) impedes their ability to empathize with clients, which may then lead to decreased sensitivity to cultural issues in case conceptualization and client treatment. The findings from our investigation, combined with Constantine's results, suggest that colorblindness is important to understanding the relationship between empathy and cultural sensitivity in counseling. 
NOT THE PUBLISHED VERSION; this is the author's final, peer-reviewed manuscript. The published version may be accessed by following the link in the citation at the bottom of the page.

Additionally, we anticipated that an interaction effect would emerge between therapist color-blindness, race of the client, and client attributions of the source of the problem. The findings did not support this interaction effect and instead indicated that therapist color-blind attitudes were directly related to therapists' self-reported levels of empathy. It would appear that therapists who were more aware of and sensitive to racial matters generally demonstrated greater empathy regardless of client race or client attributions of the source of the problem. There may be a few alternative explanations that help clarify these findings. First, the measure of empathy that we chose for this investigation was a general assessment of empathy. Perhaps a measure of empathy more attuned to cultural issues would have been more sensitive to the racial concerns in this investigation. Alternatively, Ponterotto, Costa, and Werner-Lin (2002) have suggested that cultural adaptability-flexibility (i.e., the ability to adapt to multiple cultural environments), as measured by the COBRAS (Neville et al., 2000), has direct implications for the development of individuals' interpersonal and intrapersonal abilities. Relevant to this study, therapists who are high in color-blindness may be less skilled at communicating empathy with clients, whereas therapists who are lower in color-blind racial attitudes may have a greater range of empathy, resulting in sensitivity to a wide range of client diversity, including racial-cultural diversity.

A second major finding of this study was that therapist colorblindness, race of the client, and client attributions of the cause (i.e., depression, discrimination) of the problem were not significantly related to therapists' attributions of client responsibility for the cause of a problem. In the context of the present study, it appears that neither therapists' increased awareness of racial issues, the client's race, nor the client's attributions regarding the problem cause (i.e., discrimination, depression) influenced therapists' perceptions of client responsibility for the cause of the problem. These findings are puzzling in that we might expect therapists high in color-blindness to minimize the impact of discrimination, particularly for the African American client. Although prior research suggests that therapists make different attributions for cause of the problem when there is a clear external precipitant (Hayes \& Wall, 1998; Worthington \& Atkinson, 1996), the present findings did not support this position. Furthermore, the therapists' attributions in this study were consistent with client 
attributions about the source of the problem identified in each of the vignettes.

A few alternative explanations may account for these findings. First, the limited information included in the vignettes may not have provided enough information for the respondents, especially given their experience level (mean of 20 years of experience as a psychologist), which then affected the range and quality of therapist attribution ratings.

Alternatively, it is also possible that the identified theoretical orientation of the participant influenced her or his ratings of client responsibility for the cause of the problem. Psychotherapy is influenced by Western/European American values, which emphasize an individual's personal responsibility for the change process (D. W. Sue \& Sue, 2003). As many multicultural theorists have acknowledged (e.g., Ponterotto \& Casas, 1991; D. W. Sue \& Sue, 2003), therapeutic approaches that emphasize individualism and personal responsibility may be detrimental to clients, particularly to clients of color, when life circumstances such as discrimination are beyond their immediate control.

Finally, the present practice of psychotherapy reflects guidelines set forth by insurance companies and managed care, which have resulted in an emphasis on time-limited, or briefer, solution-oriented therapy (Averill, Ruiz, Small, Guynn, \& Tcheremissine, 2003; Franko \& Erb, 1998; Sanchez \& Turner, 2003). These therapeutic approaches often emphasize solutions and are less focused on the direct causes of client problems. Given that our sample is of present practitioners, our results may reflect this change in focus in contemporary clinical practice.

A third major finding of this study was the statistically significant interaction effect found between race of the client and level of therapist color-blindness on therapists' attributions of client responsibility for the solution to a problem. Post hoc analyses additionally yielded a finding that therapists high in color-blindness rated African American clients more responsible for solving their problems than did therapists who were low in color-blindness. By contrast, no significant differences were found between therapists who 
were low, moderate, and high in color-blindness and their attribution ratings of client responsibility for the solution to the problem for the European American client. These findings are consistent with our hypotheses (i.e., therapists high in color-blindness would attribute more responsibility to the African American client than to the European American client) and also with Neville et al.'s (2001) conceptualization of color-blindness, suggesting that a therapist may hold an African American client more responsible for the solution to her or his problems when the therapist is color-blind to the racial issues present in the client's life. One implication here is that therapist bias, in the form of color-blindness, influences the attributions therapists make in counseling. As others have stated (e.g., Ponterotto et al., 2000; Ridley, 1995; D. W. Sue \& Sue, 2003), these results highlight the importance of therapists working on their own biases and developing an awareness of the impact that these biases may have on their work with racially and culturally diverse clients. Color-blind racial attitudes may indeed be a "critical component" to multicultural competency (Neville et al., 2001) and may have broader implications for client care.

\section{Limitations}

The participants in this investigation were psychologists who volunteered to take part in a study using an analogue design and selfreport measures. The results thus may have limited external validity and generalizability to psychologists' reactions in actual therapeutic practice. Relatedly, volunteer participants' beliefs and attributions may not be reflective of all practicing psychologists, although our sample was representative of the APA Practice Directorate. An additional constraint of the analogue design is the difficulty participants may experience when providing ratings on the basis of limited information included in a vignette that may or may not reflect the realities of clinical practice. It is also possible that other therapist characteristics (e.g., level of multicultural counseling training, discomfort discussing racial issues) may have influenced the findings, as may have the return rate of $32 \%$. However, Krosnick (1999) indicated that it may be more important to demonstrate that the respondents to a survey are demographically comparable to the original survey sample and the target population than the actual response rate, which we were able to 
establish for this investigation. Relatedly, we recognize that our sample was predominately European American, and thus, the findings may have limited generalizability to psychologists of color. Finally, the coefficient alphas for the MCSDS (Crowne \& Marlowe, 1960; i.e.,.65) and IRI (Davis, 1983; i.e.,.69 for the Empathic Concern subscale and.72 for the Perspective-Taking subscale) were in the low to moderate range for the respondents in this study, thus restricting the available variance.

\section{Implications}

An important impetus for this investigation was Atkinson and Lowe's (1995) assertion that researchers had not yet examined the effect of therapist biases on counseling processes. The findings from our investigation do indeed suggest that therapist biases influence therapeutic characteristics, particularly those of empathy and attributions. A few topics are thus worthy of future research. First, the relationship found between color-blindness, empathy, and attributions needs further investigation. For example, does color-blindness serve as a moderating variable in therapists' capacity for empathy and attributions of client responsibility for the solution to a problem in real counseling situations? It may also be possible to extend Constantine's (2001) research, which has examined the relationship between empathy and case conceptualization. For instance, perhaps therapists' color-blindness affects their ability to conceptualize a case in a racially and culturally sensitive way. Second, future research should explore ways of assessing clients' perceptions of therapist color-blindness, empathy, and attributions and the effect of these client perceptions on counseling processes. Third, it is important that this research be extended beyond analogue designs to field investigations. Finally, therapists in this study did not differ in their capacity for empathy or for attributions of responsibility for the cause of and solution to a problem for the African American client who attributed the problem to an external cause for his difficulties (i.e., discrimination) in comparison to an internal cause (i.e., depression). This finding is puzzling given that prior research (Hayes \& Wall, 1998; Worthington \& Atkinson, 1996) suggests that therapists do make different attributions of responsibility for the cause of and solution to a problem when there is a clear external precipitant for the problem. Perhaps the answer can 
be found in therapists' reactions to client reports of racism and discrimination in therapy. Future researchers may want to examine therapist perceptions, understanding, and judgment regarding client reports of racial discrimination.

Finally, a second impetus for this study was Garb's (1997) analysis of the clinical judgment literature and his finding that clinical judgments tended to favor groups that have historically experienced discrimination. Absent from the research designs of these prior investigations was a measure that directly assessed the racial attitudes of participating therapists. The findings from our investigation suggest that therapist color-blindness, a form of therapist bias, directly influences therapists' empathy and attributions in an analogue counseling situation. Future investigators should consider using a measure of racial bias as a potential moderating variable in clinical judgment research. Doing so may help us learn how therapists' biases affect their judgments in therapy and ultimately may help us improve the quality of care to all clients, including clients of color.

\section{References}

Abramowitz, S. I., \& Murray, J. (1983). Race effects in psychotherapy. In J.Murray \& P. R.Abramson (Eds.), Bias in psychotherapy (pp. 215255). New York: Praeger Publishers.

American Psychological Association. (1997). Can or should Americans be color-blind?Psychological research reveals fallacies in a color-blind response to racism. [Pamphlet]. Washington, DC: Author.

Atkinson, D. R., Casas, A., \& Abreu, J. (1992). Mexican-American acculturation, counselor ethnicity and cultural sensitivity, and perceived counselor competence. Journal of Counseling Psychology, $39,515-520$.

Atkinson, D. R., \& Lowe, S. M. (1995). The role of ethnicity, cultural knowledge, and conventional techniques in counseling and psychotherapy. In J. G.Ponterotto, J. M.Casas, L. A.Suzuki, \& C. M.Alexander (Eds.), Handbook of multicultural counseling (pp. 387414). Thousand Oaks, CA: Sage. 
NOT THE PUBLISHED VERSION; this is the author's final, peer-reviewed manuscript. The published version may be accessed by following the link in the citation at the bottom of the page.

Averill, P. M., Ruiz, P., Small, D. R., Guynn, R. W., \& Tcheremissine, O. (2003). Outcome assessment of the Medicaid managed care program in Harris County (Houston)Psychiatric Quarterly, 74, 103-114.

Bailey, J., \& Hayes, J. A. (1998). Religious attributions of responsibility: A review of empirical literature and development of an instrument. Counseling and Values, 43, 49-62.

Baldwin, J. (1998). White man's guilt. In D.Roediger (Ed.), Black on White: Black writers on what it means to be White (pp. 320-325). New York: Schoken Books. (Original work published 1965)

Bamgbose, O., Edwards, D., \& Johnson, S. (1980). The effects of race and social class on clinical judgment. Journal of Clinical Psychology, 36, 605-609.

Bernstein, W. M., \& Davis, M. H. (1982). Perspective-taking, selfconsciousness, and accuracy in person perception. Basic and Applied Social Psychology, 3, 1-19.

Bohart, A. C., Elliot, R., Greenberg, L. S., \& Watson, J. C. (2002). In J. C.Norcross (Ed.), Psychotherapy relationships that work: Therapist contributions and responsiveness to patients (pp. 89-108). London: Oxford University Press.

Brickman, P., Rabinowitz, V. C., Karuza, J., Coates, D., Cohn, E., \& Kidder, L. (1982). Models of helping and coping. American Psychologist, 37, 368384.

Burkard, A. W., Medler, B. R., \& Boticki, M. A. (2001). Prejudice and racism: Challenges and progress in measurement. In J. G.Ponterotto, J. M.Casas, L. A.Suzuki, \& C. M.Alexander (Eds.), Handbook of multicultural counseling (2nd ed., (pp. 457-481). Thousand Oaks, CA: Sage.

Butcher, J. N., Braswell, L., \& Raney, D. (1983). A cross-cultural comparison of American Indian, Black, and White inpatients on the MMPI and presenting symptoms. Journal of Consulting and Clinical Psychology, 51, 587-594.

Constantine, M. G. (2000). Social desirability attitudes, sex, and affective and cognitive empathy as predictors of self-reported multicultural counseling competence. The Counseling Psychologist, 28, 857-872. 
NOT THE PUBLISHED VERSION; this is the author's final, peer-reviewed manuscript. The published version may be accessed by following the link in the citation at the bottom of the page.

Constantine, M. G. (2001). Multicultural training, theoretical orientation, empathy, and multicultural case conceptualization ability in counselors. Journal of Mental Health Counseling, 23, 357-372.

Constantine, M. G. (2002). Predictors of satisfaction with counseling: Racial and ethnic minority clients' attitudes toward counseling and ratings of their counselors' general and multicultural competence. Journal of Counseling Psychology, 49, 255-263.

Constantine, M. G., Juby, H. L., \& Liang, J. J.-C. (2001). Examining multicultural counseling competence and race-related attitudes among White marital and family therapists. Journal of Marital and Family Therapy, 27, 353-362.

Constantine, M. G., \& Ladany, N. (2000). Self-report multicultural counseling competence scales: Their relationship to social desirability attitudes and multicultural case conceptualization ability. Journal of Counseling Psychology, 47, 155-164.

Crowne, D. P., \& Marlowe, D. (1960). A new scale of social desirability independent of psychopathology. Journal of Consulting Psychology, 24, 349-354.

Davis, M. (1980). A multidimensional approach to individual differences in empathy. JSAS: Catalog of Selected Documents in Psychology, 10, 85.

Davis, M. H. (1983). Measuring individual differences in empathy: Evidence for a multidimensional approach. Journal of Personality and Social Psychology, 44, 113-126.

Davis, M. H., Hull, J. G., Young, R. D., \& Warren, G. G. (1987). Emotional reactions to dramatic film stimuli: The influence of cognitive and emotional empathy. Journal of Personality and Social Psychology, 52, 126-133.

Donnan, H., \& Pipes, R. (1985). Counselor trainees' explanation of behavior: Attributions to traits, situations, and interactions. Journal of Clinical Psychology, 41, 729-733.

Fischer, A. R., Jome, L. M., \& Atkinson, D. R. (1998). Reconceptualizing multicultural counseling: University healing conditions in a culturally specific context. The Counseling Psychologist, 26, 525-588. 
NOT THE PUBLISHED VERSION; this is the author's final, peer-reviewed manuscript. The published version may be accessed by following the link in the citation at the bottom of the page.

Franko, D. L., \& Erb, J. (1998). Managed care or mangled care? Treating eating disorders in the current healthcare climate. Psychotherapy: Theory, Research, Practice, Training, 35, 43-53.

Gaertner, S. L., \& Dovidio, J. F. (1986). The aversive form of racism. In J. F.Dovidio \& S. L.Gaertner (Eds.), Prejudice, discrimination, and racism (pp. 61-89). New York: Academic Press.

Garb, H. N. (1997). Race bias, social class bias, and gender bias in clinical judgment. Clinical Psychology: Science and Practice, 4, 99-120.

Gim, R. H., Atkinson, D. R., \& Kim, S. J. (1991). Asian-American acculturation, counseling ethnicity and cultural sensitivity, and ratings of counselors. Journal of Counseling Psychology, 38, 57-62.

Gynther, M. D. (1972). White norms and black MMPIs: A prescription for discrimination?Psychological Bulletin, 78, 386-402.

Gynther, M. D. (1979). Ethnicity and personality: An update. In J. N.Butcher (Ed.), New developments in the use of the MMPI (pp. 113-140). Minneapolis: University of Minnesota Press.

Hayes, J. A., \& Erkis, A. J. (2000). Therapist homophobia, client sexual orientation, and source of client HIV infection as predictors of therapist reactions to clients with HIV. Journal of Counseling Psychology, 47, 71-78.

Hayes, J. A., \& Wall, T. N. (1998). What influences clinicians' responsibility attributions? The role of problem type, theoretical orientation, and client attribution. Journal of Social and Clinical Psychology, 17, 69-74.

Helms, J. E. (1984). Toward a theoretical explanation of the effects of race on counseling: A Black and White model. The Counseling Psychologist, 12, 153-165.

Helms, J. E. (1990). Toward a model of White racial identity. In J. E.Helms (Ed.), Black and White racial identity: Theory, research, and practice (pp. 40-65). Westport, CT: Praeger Publishers.

Ho, M. K. (1992). Minority children and adolescents in therapy. Newbury Park, CA: Sage. 
NOT THE PUBLISHED VERSION; this is the author's final, peer-reviewed manuscript. The published version may be accessed by following the link in the citation at the bottom of the page.

Karuza, J., Zevon, M. A., Gleason, T. A., Karuza, C. K., \& Nash, L. (1990). Models of helping and coping, responsibility attributions, and wellbeing in community elderly and their helpers. Psychology and Aging, 5, 194-208.

Kovel, J. (1970). White racism: A psychohistory. New York: Pantheon Books.

Krebs, R. L. (1971). Some effects of a White institution on Black psychiatric outpatients. American Journal of Orthopsychiatry, 41, 589-597.

Krosnick, J. A. (1999). Survey research. Annual Review of Psychology, 50, 537-567.

Lafferty, P., Beutler, L. E., \& Crago, M. (1989). Differences between more and less effective psychotherapists: A study of select therapist variables. Journal of Consulting and Clinical Psychology, 57, 76-80.

LaFromboise, T. D. (1988). American Indian mental health policy. American Psychologist, 43, 388-397.

Leong, F. T. (1985). Career development of Asian Americans. Journal of College Student Personnel, 26, 539-546.

Leung, S. A. (1995). Career development and counseling: A multicultural perspective. In J. G.Ponterotto, J. M.Casas, L. A.Suzuki, \& C. M.Alexander (Eds.), Handbook of multicultural counseling (pp. 549566). Thousand Oaks, CA: Sage.

McConahay, J. B. (1986). Modern racism, ambivalence, and the Modern Racism Scale. In J. F.Dovidio \& S. L.Gaertner (Eds.), Prejudice, discrimination, and racism (pp. 91-125). New York: Academic Press.

McCracken, J. E., Hayes, J. A., \& Dell, D. (1997). Attributions of responsibility for memory problems in older and younger adults. Journal of Counseling \& Development, 75, 385-391.

Michlitsch, J. F., \& Frankel, S. (1989). Helping orientations: Four dimensions. Perceptual \& Motor Skills, 69, 1371-1378.

Neville, H. A., Lilly, R. L., Duran, G., Lee, R., \& Browne, L. (2000). Construction and initial validation of the Color-Blind Racial Attitudes Scale (COBRAS)Journal of Counseling Psychology, 47, 59-70. 
NOT THE PUBLISHED VERSION; this is the author's final, peer-reviewed manuscript. The published version may be accessed by following the link in the citation at the bottom of the page.

Neville, H. A., Worthington, R. L., \& Spanierman, L. B. (2001). Race, power, and multicultural counseling psychology: Understanding White privilege and color-blind racial attitudes. In J. G.Ponterotto, J. M.Casas, L. A.Suzuki, \& C. M.Alexander (Eds.), Handbook of multicultural counseling (2nd ed., (pp. 257-288). Thousand Oaks, CA: Sage.

Paulhus, D. L. (1984). Two-component models of socially desirable responding. Journal of Personality and Social Psychology, 46, 598609.

Paulhus, D. L. (1991). Measurement and control of response bias. In J. B.Robinson, P. R.Shaver, \& L. S.Wrightsman (Eds.), Measure of personality and social psychological attitudes (pp. 17-59). San Diego, CA: Academic Press.

Pavkov, T. W., Lewis, D. A., \& Lyons, J. S. (1989). Psychiatric diagnoses and racial bias: An empirical investigation. Professional Psychology: Research and Practice, 20, 364-368.

Pomales, J., Claiborn, C. D., \& LaFromboise, T. D. (1986). Effects of Black students' racial identity on perceptions of White counselors varying in cultural sensitivity. Journal of Counseling Psychology, 33, 57-61.

Ponterotto, J. G., Burkard, A. W., Rieger, B. P., Grieger, I., D'Onofrio, A., Dubuisson, A., et al. (1995). Development and initial validation of the Quick Discrimination Index (QDI)Educational and Psychological Measurement, 55, 1016-1031.

Ponterotto, J. G., \& Casas, J. M. (1991). Handbook of racial/ethnic minority counseling research. Springfield, IL: Charles C Thomas.

Ponterotto, J. G., Costa, C. I., \& Werner-Lin, A. (2002). Research perspectives in cross-cultural counseling. In P. B.Pedersen, J. G.Draguns, W. J.Lonner, \& J. E.Trimble (Eds.), Counseling across cultures (5th ed., (pp. 395-420). Thousand Oaks, CA: Sage.

Ponterotto, J. G., Fuertes, J. N., \& Chen, E. (2000). Models of multicultural counseling. In S. E.Brown \& R. W.Lent (Eds.), Handbook of counseling psychology (3rd ed., (pp. 639-669). New York: Wiley. 
NOT THE PUBLISHED VERSION; this is the author's final, peer-reviewed manuscript. The published version may be accessed by following the link in the citation at the bottom of the page.

Reynolds, W. M. (1982). Development of reliable and valid short forms of the Marlowe-Crowne Social Desirability Scale. Journal of Clinical Psychology, 38, 119-125.

Ridley, C. R. (1995). Overcoming unintentional racism in counseling and therapy: A practitioner's guide to intentional interventions. Thousand Oaks, CA: Sage.

Ridley, C. R., \& Lingle, D. W. (1996). Cultural empathy in multicultural counseling: A multidimensional process model. In P. B.Pedersen, J. G.Draguns, W. J.Lonner, \& J. E.Trimble (Eds.), Counseling across cultures (4th ed., (pp. 21-46). Thousand Oaks, CA: Sage.

Root, M. P. P. (1998). Facilitating psychotherapy with Asian American clients. In D. R.Atkinson, G.Morten, \& D. W.Sue (Eds.), Counseling American minorities (5th ed., (pp. 214-234). New York: McGraw-Hill.

Sanchez, L. M., \& Turner, S. M. (2003). Practicing psychology in the era of managed care: Implications for practice and training. American Psychologist, 58, 116-129.

Schofield, J. W. (1986). Causes and consequences of the color-blind perspective. In J. F.Dovidio \& S. L.Gaertner (Eds.), Prejudice, discrimination, and racism (pp. 231-253). New York: Academic Press.

Serrano, R. A. (1998, March4). Study counts record number of hate groups, 20\% jump in year. San Francisco Chronicle. p. A5.

Smith, E. J. (1983). Issues in ethnic minorities' career behavior. In W. B.Walsh \& S. H.Osipow (Eds.), Handbook of vocational psychology (Vol. 1, pp. 161-222). Hillsdale, NJ: Erlbaum.

SPSS. (1999). SPSS base 10.0 user's guide. Chicago: Author.

Stevens, J. (2002). Applied multivariate statistics for the social sciences. Hillsdale, NJ: Erlbaum.

Sue, D. W., Bernier, J. E., Durran, A., Feinberg, L., Pedersen, P., Smith, E. J., \& Vasquez-Nuttall, E. (1982). Position paper: Cross-cultural counseling competencies. The Counseling Psychologist, 10, 45-52.

Sue, D. W., \& Sue, D. (2003). Counseling the culturally diverse: Theory and practice (4th ed.). New York: Wiley. American Psychological Association does not grant permission for this article to be further copied/distributed or hosted elsewhere without the express permission from American Psychological Association. 
NOT THE PUBLISHED VERSION; this is the author's final, peer-reviewed manuscript. The published version may be accessed by following the link in the citation at the bottom of the page.

Sue, S., Fujino, L. H., Hu, L.-T., Takeuchi, D. T., \& Zane, N. W. (1991). Community mental health services for ethnic minority groups: A test of the cultural responsiveness hypothesis. Journal of Counseling and Clinical Psychology, 59, 533-540.

Terrell, F., \& Terrell, S. (1984). Race of counselor, client sex, cultural mistrust level, and premature termination from counseling among Black clients. Journal of Counseling Psychology, 31, 371-375.

Thompson, C. E., \& Jenal, S. T. (1994). Interracial and intraracial quasicounseling interactions when counselors avoid discussing race. Journal of Counseling Psychology, 41, 484-491.

Thompson, C. E., Worthington, R., \& Atkinson, D. R. (1994). Counselor content orientation, counselor race, and Black women's cultural mistrust and self-disclosures. Journal of Counseling Psychology, 41, $155-161$.

Tracey, T. J. (1988). Relationship of responsibility attribution congruence to psychotherapy outcome. Journal of Social and Clinical Psychology, 7, 131-146.

U.S. Department of Commerce. (1998). Census Bureau current population reports. (Series P-60, Selected issues). Washington, DC: U.S. Government Printing Office.

Wade, P., \& Bernstein, B. L. (1991). Culture sensitivity training and counselor's race: Effects on Black female clients' perceptions and attrition. Journal of Counseling Psychology, 38, 9-15.

Williams, P. J. (1997). Seeing a color-blind future: The paradox of race. New York: Farrar, Straus \& Giroux.

Worthington, R. L., \& Atkinson, D. R. (1996). Effects of perceived etiology attribution similarity on client ratings of counselor credibility. Journal of Counseling Psychology, 43, 423-429.

Yamamoto, J., James, Q., Bloombaum, M., \& Hattem, J. (1967). Racial factors in patient selection. American Journal of Psychiatry, 124, 630-636.

\section{Notes:}

- Alan W. Burkard and Sarah Knox, Department of Counseling and Educational Psychology, School of Education, Marquette University.

Journal of Counseling Psychology, Vol. 51, No. 4 (October 2004): pg. 387-397. DOI. This article is (C) American Psychological Association and permission has been granted for this version to appear in e-Publications@Marquette. American Psychological Association does not grant permission for this article to be further copied/distributed or hosted elsewhere without the express permission from American Psychological Association. 
NOT THE PUBLISHED VERSION; this is the author's final, peer-reviewed manuscript. The published version may be accessed by following the link in the citation at the bottom of the page.

- We thank all of the psychologists who participated in this study. We also thank Adanna J. Johnson and John P. Lombardo for their assistance in coordinating the mailing and data entry. Finally, Robert Fox and Barbara Medler reviewed an earlier version of this article and Lauren Leslie provided statistical consultation, and we thank them for their feedback and suggestions.

- Correspondence concerning this article should be addressed to Alan W. Burkard, Department of Counseling and Educational Psychology, School of Education, Marquette University, P.O. Box 1881, Milwaukee, WI 53201-1881. E-mail: alan.burkard@marquette.edu 
NOT THE PUBLISHED VERSION; this is the author's final, peer-reviewed manuscript. The published version may be accessed by following the link in the citation at the bottom of the page.

\section{Appendix}

\section{Table 1}

Means, Standard Deviations, and Intercorrelations of Dependent, Independent, and Covariate Variables

\begin{tabular}{|l|c|c|c|c|c|c|c|}
\hline Variable & $\boldsymbol{M}$ & SD & $\mathbf{1}$ & $\mathbf{2}$ & $\mathbf{3}$ & $\mathbf{4}$ & $\mathbf{5}$ \\
\hline 1. COBRAS & 53.29 & 13.79 & - & .01 & $.18^{* *}$ & .06 & $-.19^{* *}$ \\
\hline 2. MCSDS & 14.99 & 4.26 & & - & $.16^{*}$ & $.21^{* *}$ & $.13^{*}$ \\
\hline 3. Cause of the problem & 10.62 & $\mathbf{3 . 6 8}$ & & & - & $.39^{* *}$ & -.01 \\
\hline 4. Solution to the problem & 16.27 & 2.70 & & & & - & .09 \\
\hline 5. Empathy & 41.25 & 5.73 & & & & & - \\
\hline
\end{tabular}

Note. COBRAS $=$ Color-Blind Racial Attitudes Scale; MCSDS $=$ Marlowe-Crowne Social Desirability Scale. $* \mathrm{p}<.05 . * * \mathrm{p}<.01$.

Table 2

Descriptive Statistics by Race of Client, Source of Problem, and Level of Color-Blindness on Measures of Therapist Attributions of Client Cause of and Solution to the Problem, and Empathy

\begin{tabular}{|c|c|c|c|c|c|c|r|}
\hline & \multicolumn{2}{|c|}{ Cause } & \multicolumn{2}{c|}{ Solution } & \multicolumn{2}{c|}{ Empathy } & \\
\hline Condition & $M$ & $S D$ & $M$ & $S D$ & $M$ & $S D$ & $n$ \\
\hline African American & 9.88 & 3.88 & 15.68 & 2.72 & 41.07 & 6.21 & 127 \\
\hline Discrimination & 9.92 & 4.27 & 14.89 & 2.74 & 40.70 & 5.87 & 64 \\
\hline Low CB & 9.48 & 4.23 & 14.39 & 3.00 & 42.35 & 5.24 & 23 \\
\hline Moderate CB & 8.95 & 4.71 & 14.29 & 2.83 & 40.14 & 5.25 & 21 \\
\hline High CB & 11.45 & 3.58 & 16.10 & 1.95 & 39.40 & 6.91 & 20 \\
\hline Depression & 9.83 & 3.47 & 16.48 & 2.47 & 41.45 & 6.56 & 63 \\
\hline Low CB & 8.00 & 2.90 & 15.95 & 2.04 & 41.44 & 8.32 & 20 \\
\hline Moderate CB & 10.62 & 2.79 & 16.16 & 2.25 & 41.25 & 5.28 & 25 \\
\hline High CB & 10.78 & 4.19 & 17.50 & 2.98 & 41.72 & 6.39 & 18 \\
\hline European American & 11.40 & 3.30 & 16.90 & 2.55 & 41.44 & 5.17 & 120 \\
\hline Discrimination & 11.17 & 3.30 & 16.52 & 2.41 & 41.48 & 5.11 & 65 \\
\hline Low CB & 11.50 & 3.30 & 16.20 & 2.71 & 44.05 & 4.98 & 20 \\
\hline Moderate CB & 11.10 & 3.45 & 17.23 & 2.34 & 42.23 & 4.06 & 21 \\
\hline High CB & 10.96 & 3.29 & 16.17 & 2.16 & 38.67 & 4.84 & 24 \\
\hline Depression & 11.67 & 3.32 & 17.35 & 2.67 & 41.40 & 5.30 & 55 \\
\hline Low CB & 10.94 & 3.11 & 17.56 & 2.62 & 42.39 & 5.45 & 18 \\
\hline Moderate CB & 11.50 & 3.95 & 17.69 & 1.96 & 40.81 & 4.10 & 16 \\
\hline High CB & 12.43 & 2.94 & 16.90 & 3.19 & 41.00 & 6.05 & 21 \\
\hline
\end{tabular}

Note. $\mathrm{CB}=$ Color-blindness.

Journal of Counseling Psychology, Vol. 51, No. 4 (October 2004): pg. 387-397. DOI. This article is (c) American Psychological Association and permission has been granted for this version to appear in e-Publications@Marquette. American Psychological Association does not grant permission for this article to be further copied/distributed or hosted elsewhere without the express permission from American Psychological Association. 